\title{
Preferensi Gaya Belajar Perseptual Siswa Sekolah Menengah Pertama
}

\section{Perceptual Learning Style Preference of Junior High School Students}

\author{
Darin Fadhilah \& Didi Suherdi \\ Universitas Pendidikan Indonesia, Bandung, Jawa Barat, Indonesia \\ darinfadhilah@upi.edu
}

Naskah diterima tanggal 23/12/2019, direvisi akhir tanggal 06/08/2020, disetujui tanggal 30/08/2020

\begin{abstract}
Abstrak
Penelitian ini dilakukan untuk mengetahui preferensi gaya atau tipe belajar siswa pada sekolah dasar menengah, dan untuk melihat apakah ada perbedaan antara preferensi gaya belajar siswa laki-laki dan perempuan. Sampel penelitian ini adalah 27 siswa siswa SMP, 12 siswa perempuan dan 15 siswa laki-laki. Penelitian ini adalah penelitian kuantitatif yang menggunakan Kuesioner Perceptual Learning oleh Reid (1987) sebagai instrumen. Hasil penelitian menunjukkan bahwa gaya belajar yang disukai siswa adalah gaya belajar kelompok, sedangkan gaya belajar yang paling tidak disukai adalah gaya belajar individu, disimpulkan bahwa murid laki dan perempuan memang berbeda secara unik dalam preferensi mereka pada gaya belajar.
\end{abstract}

Kata kunci: Siswa EFL, Gaya Belajar, Gaya Belajar Perseptual

\begin{abstract}
This study is conducted to find out both the major and minor learning style of students, and to see if there any difference between the male and female students' preferences based onThe Perceptual Learning Style. The sample of the study were 27 students of junior high school students, there were 12 female students and 15 male students. This study was a quantitative study which used Reid's Perceptual Learning Style Questionnaire as the instrument. The result shows that the major learning style of the students is group learning style, while the least preferred learning style is individual learning style, and it concludes that male and female indeed uniquely different in their preference on learning style.
\end{abstract}

Keywords: EFL Students, Learning Style, Perceptual Learning Style

\section{PENDAHULUAN}

Dalam bidang penelitian bahasa, salah satu topik penilitian adalah gaya belajar siswa, terlepas dari strategi atau metode belajar yang digunakan oleh guru, siswa memiliki gaya belajarnya sendiri, teori tersebut memiliki landasan yang disarankan oleh Claxton dan Ralston (1978) menyatakan bahwa tiap individu memiliki cara yang konsisten dalam merespons dan menggunakan rangsangan dalam konteks pembelajaran. Dengan demikian, jelas bahwa setiap orang memiliki cara belajar yang berbeda, termasuk siswa yang mempelajari bahasa Inggris sebagai bahasa Asing (English as Foreign Language). Hal ini harus dipertimbangkan oleh guru. Para guru perlu mengidentifikasi gaya belajar yang disukai dan kurang disukai oleh mayoritas siswa terlebih dahulu sebelum memutuskan pendekatan yang tepat, dan metode dalam proses mengajar di kelas untuk memfasilitasi dan mendukung siswa.

Berdasarkan hal tersebut, penelitian ini dilakukan untuk mengetahui gaya belajar 
utama dan kedua siswa berdasarkan Gaya Belajar Perseptual oleh Reid (Reid, 1987), dan untuk melihat apakah ada perbedaan antara preferensi siswa laki-laki dan perempuan dalam gaya belajar mereka, apakah diperlukannya penyesuaian pendekatan dan metode untuk siswa berdasarkan kebutuhan mereka yang mencakup gaya belajar mereka.

Sebuah penelitian oleh Gilakjani (2012), tentang gaya belajar visual, auditori, kinestetik serta dampaknya pada pengajaran bahasa Inggris yang menggunakan kuesioner preferensi gaya belajar perseptual oleh Reid (1987), menunjukkan bahwa dari 100 mahasiswa Iran Efl, preferensi gaya belajar perseptual Reid yang paling disenangi adalah gaya belajar visual.

Penelitian lain tentang preferensi gaya belajar pembelajar bahasa inggris oleh Karthigeyan dan Nirmala (2013) menunjukkan bahwa dari 582 siswa sekolah menengah atas di distrik Salem, negara bagian Tamilnadu, gaya belajar yang paling disenangi adalah gaya belajar visual dan auditori.

Sebuah penelitian tentang preferensi siswa pada gaya belajar perseptual oleh Obralic dan Akbarov (2012) menunjukkan bahwa dari 34 mahasiswa Universitas Internasional Saravejo, preferensi gaya belajar perseptual yang paling disenangi adalah gaya belajar visual. Penelitian ini juga bertujuan mengetahui perbedaan antara preferensi siswa pria dan wanita pada gaya belajar perseptual Reid, namun tidak ada perbedaan yang signifikan antara siswa pria dan wanita mengenai preferensi studi mereka.

Sebagian besar penelitian yang telah disebutkan di atas, menunjukkan bahwa gaya belajar visual adalah yang paling disukai oleh siswa, namun Nel (2008) menyarankan bahwa penelitian tentang gaya belajar masih perlu dilakukan untuk memiliki informasi yang lebih baik, terutama apakah gaya belajar visual adalah gaya belajar yang paling disukai. Oleh karena itu, peneliti tertarik untuk mengetahui gaya belajar yang paling disukai siswa di suatu sekolah menengah pertama di Jawa Barat yang didasarkan pada teori Gaya Belajar Reid (1987) terkait dengan gaya belajar persepsi.

Dalam penelitian ini, peneliti ingin mengetahui gaya belajar yang paling disukai siswa berdasarkan klasifikasi gaya belajar perseptual Reid, khususnya, gaya belajar dominan atau paling disukai dan yang tidak disukai. Selanjutnya, peneliti ingin tahu apakah ada perbedaan antara preferensi siswa laki-laki dan perempuan berdasarkan klasifikasi gaya belajar perseptual Reid.

Ada beberapa pertanyaan yang mendasari penelitian ini yaitu (1) Apa gaya belajar dominan siswa berdasarkan klasifikasi gaya belajar persepsi Reid?; (2) Apa gaya belajar yang kurang diminati siswa berdasarkanklasifikasigayabelajarperseptual Reid?; (3) Apakah ada perbedaan antara preferensi siswa pria dan wanita berdasarkan klasifikasi gaya belajar perseptual Reid? Maka, penelitian ini bertujuan dan terbatas untuk mengetahui preferensi gaya belajar siswa berdasarkam klasifikasi gaya belajar Reid di kelas dan untuk melihat apakah ada perbedaan antara siswa pria dan wanita mengenai preferensi gaya belajar mereka.

Hasil penelitian ini diharapkan dapat menjadi informasi yang mendukung bagi guru dan siswa. Informasi ini diharapkan dapat membantu guru mempersiapkan media dan materi yang tepat yang disesuaikan dengan preferensi gaya belajar siswa untuk mendukung kebutuhan siswa. Hal ini juga diharapkan dapat membantu siswa untuk memahami jenis gaya belajar mereka yang paling sesuai. Selanjutnya, penelitian ini diharapkan dapat memberikan informasi kepada mereka yang tertarik pada bidang penelitian ini.

\subsection{Konsep Gaya Belajar}

Asal usul konsep dan teori gaya belajar bermula dari bidang psikologi, lalu berkembang di luar bidang psikologi untuk mengintegrasikan teori gaya belajar pada konteks pembelajaran dan pendidikan ( $\mathrm{Nel}$, 2008). Di bidang penelitian bahasa, teori gaya belajar diawali oleh Claxton dan Ralston (1978) yang menyatakan bahwa setiap pelajar memiliki cara yang konsisten dalam menanggapi dan menggunakan rangsangan dalam konteks belajar. Dengan demikian 
metode pengajaran menjadi proses belajar mengajar pada setiap siswa akan belajar melalui gaya belajar pilihannya sendiri. Oleh karena itu, jelas bahwa setiap orang memiliki cara belajar bahasa yang berbeda.

Brown (2007) mendefinisikan gaya belajar sebagai cara manusia belajar sesuatu dan menyelesaikan masalah yang berkaitan dengan kepribadian serta kognitif dimana hal tersebut dapat dipengaruhi oleh faktor afektif dan fisiologis. Sementara Skehan (1991) mendefinisikan gaya belajar sebagai "kecenderunga yang baik sadar atau tidak, terhadap pemrosesan informasi dengan cara tertentu". Sebagai contoh, gaya belajar mengacu pada preferensi pelajar untuk memproses informasi, menyelesaikan atau mengerjakan tugas.

\subsection{Preferensi Gaya Belajar}

Beberapa penelitian telah mengidentifika jenis gaya belajar yang disukai pelajar. Dunn dan Dunn (1992) mengidentifikasi lima dimensi mengenai berbagai preferensi pelajar. Pertama, preferensi lingkungan, itu adalah preferensi mengenai suara, cahaya, suhu, dan desain ruang kelas dalam proses pembelajaran. Kedua, preferensi emosional adalah motivasi, ketekunan, tanggung jawab, dan struktur belajar. Ketiga, preferensi sosiologi adalah preferensi pelajar dalam mengerjakan tugas, baik dalam pekerjaan pribadi, berpasangan, atau kerja tim. Keempat, preferensi fisiologis, ini terkait dengan kekuatan persepsi, asupan, waktu, dan mobilitas. Terakhir, preferensi impulsif/reflektif, apakah pembelajar impulsif dalam memutuskan sesuatu atau mengerjakan suatu tugas, sebaliknya, pembelajar reflektif cenderung mengambil waktu dalam memutuskan atau mengerjakan suatu tugas.

Ada beberapa konsep preferensi gaya belajar lain yang telah diidentifikasi oleh beberapa peneliti dan masing-masin memiliki konsep tersendiri tentang gaya belajar seseorang (Griffith, 2008). Misalnya, divergent versus convergent (Hudson, 1966), ketergantungan lapangan versus independensi lapangan (Witkin et al., 1954), global versus analitis (Kirby, 1988), impulsif versus reflektif (Kagan, 1965), leveler versus rautan (Schmeck, 1981), organizer versus nonorganizer (Atman, 1988), hemisfer kanan versus kiri (Torrance dan Rockenstein, 1988), pengambilan risiko versus kehati-hatian (Kogan dan Wallach, 1964; Kogan, 1971), verbalisasi versus visualizer (Richardson, 1977), visual versus haptic (Lewenfeld, 1945), holist versus analitik (Peters, 1977) dan holist versus serialis (Pask, 1972). Meskipun ada banyak gaya yang dipaparkan di atas, siswa tidak selalu hanya menampilkan satu gaya. Sebagai contoh, seorang siswa dengan gaya verbal tidak selalu berarti bahwa siswa tidak akan menampilkan elemen gaya visual.

\subsection{Gaya Belajar Perseptual}

Berdasarkan Reid (1987), ada enam preferensi gaya persepsi dasar: visual, auditori, kinestetik, taktil, kelompok, individu. Pertama, visual, Peserta didik belajar dari melihat kata-kata di buku, di papan tulis, dan di buku kerja. Peserta didik dapat memahami informasi dan instruksi dengan lebih baik jika mereka membacanya, misalnya, di kelas membaca menggunakan grafik. Kedua, pendengaran, peserta didik belajar dari mendengar kata-kata yang diucapkan dan dari penjelasan lisan. Peserta didik dapat mengingat informasi dengan membaca dengan keras atau menggerakkan bibir mereka saat mereka membaca, terutama ketika mereka mempelajari materi baru, misalnya, di kelas, mengajar menggunakan kaset. Ketiga, kinestetik yang melibatkan aktivitas fisik. Peserta didik belajar paling baik berdasarkan pengalaman, dengan terlibat secara fisik dalam pengalaman kelas. Peserta didik dapat mengingat informasi dengan baik ketika mereka secara aktif berpartisipasi dalam kegiatan, kunjungan lapangan, dan permainan peran di kelas. Keempat, sentuhan, itu adalah preferensi menggunakan model atau melakukan percobaan laboratorium, pelajar belajar melalui kesempatan untuk melakukan pengalaman "langsung" dengan materi. Misalnya, melakukan percobaan di laboratorium, menangani dan membangun model. Menulis catatan atau instruksi juga dapat membantu pelajar mengingat informasi. Kelima, kelompok, pelajar belajar dengan bekerja bersama dalam suatu 
kelompok, stimulasi yang diterima peserta didik dari interaksi kelompok membantu siswa belajar memahami informasi baru. Keenam, individu, peserta didik belajar paling baik jika mereka sendirian (Nel, 2008; Babich et al., 1976).

\subsection{Instrumen Gaya Belajar}

Dalam mengeksplorasi gaya belajar pembelajar, beberapa peneliti bahasa telah mengembangkan beberapa instrumen. Misalnya, Oxford (1993) dan Kuisioner Gaya Belajar oleh Ehrman dan Leaver (2003), Reid (1987) Kuisioner Preferensi Gaya Belajar Perceptual.

Style Analysis Survey (SAS) oleh Oxford (1993) digunakan untuk menentukan pendekatan umum peserta didik untuk belajar. Ini terdiri dari lima bagian: "menggunakan indera fisik untuk belajar atau bekerja (visual, auditori, dan langsung), berurusan dengan orang lain (ekstrovert versus introvert), menangani kemungkinan (intuitif versus sekuensial-beton), mendekati tugas (penutupan), (berorientasi versus terbuka) dan berurusan dengan ide-ide (global versus analitik)".

The Learning Styles Questionnaire atau Kuisioner Gaya Belajar oleh Ehrman dan Leaver (2003) terdiri dari konstruk superordinat (synopsis-ectasis) dan sepuluh subskala. Menurut Ehrman dan Leaver (2003), konstruksi ini menyediakan informasi siswa yang terperinci dan individual.

Kuesioner Preferensi Gaya Belajar Perceptual oleh Reid (1987) terdiri dari lima pernyataan yang disusun secara acak pada masing-masing dari enam preferensi gaya belajar yang telah disebutkan sebelumnya (visual, auditori, kinestetik, sentuhan, kelompok, dan individu). Contoh pernyataan termasuk: "Saya mengerti lebih baik ketika saya membaca instruksi," dan "Saya belajar lebih banyak ketika saya belajar dengan kelompok." Untuk setiap pernyataan, responden harus menilai setiap pernyataan pada skala 5 poin dari sangat tidak setuju sampai sangat tidak setuju.

Reid (1987) juga memberikan klasifikasi untuk menentukan apakah gaya belajar itu mayor (disukai), minor (kurang disukai) dan diabaikan sebagai parameter preferensi pelajar. Mayor mengacu pada gaya belajar yang paling disukai oleh pelajar, sedangkan minor mengacu pada gaya belajar yang kurang disukai namun dapat membantu siswa untuk belajar, dan terakhir, diabaikan mengacu pada gaya belajar yang paling tidak disukai yang juga memiliki efek yang lebih kecil di dalam proses pembelajaran.

Keuntungan dari hasil instrument tersebut untuk guru bahasa adalah bahwa mereka dapat memodifikasi pengajaran mereka sesuai dengan kebutuhan siswa mereka. Sementara bagi siswa, instrumeninstrumen itu dapat membantu mereka untuk lebih mengenal diri sendiri dan memaksimalkan kesempatan belajar mereka.

\subsection{Penelitian terdahulu}

Ada beberapa penelitian yang telah dilakukan mengenai gaya belajar siswa, khususnya mengenai gaya belajar persepsi yang digunakan dalam penelitian ini.

Sebuah penelitian yang dilakukan oleh Obralic dan Akbarov (2012) melaporkan bahwa dari 34 siswa di Universitas Internasional Saravjevo, preferensi gaya belajar yang paling diminati adalah gaya belajar visual. Mengenai perbedaan gender, baik laki-laki (18 siswa) dan perempuan (16 siswa) juga lebih suka visual sebagai gaya belajar utama mereka, dan tidak ada perbedaan yang signifikan antara siswa lakilaki dan perempuan pada gaya belajar yang mereka sukai.

Sebuah penelitian oleh Gilakjani (2012) tentang gaya belajar visual, auditori, kinaesthetic dan dampaknya pada pengajaran bahasa inggris yang menggunakan kuesioner preferensi gaya belajar persepsi Reid, menunjukkan bahwa dari 100 mahasiswa EFL Iran (40 laki-laki dan 60 siswa perempuan), sekitar $50 \%$ dari siswa lebih suka gaya belajar visual, 35\% dari siswa lebih suka gaya belajar menggunakanaudio, 15\% dari siswa lebih suka gaya kinestetik untuk pembelajaran mereka. Dengan demikian, dapat disimpulkan preferensi gaya belajar yang paling diminati di antara para siswa Iran adalah gaya belajar visual.

Penelitian lain tentang Preferensi Gaya 
Belajar Pembelajar Bahasa Inggris oleh Karthigeyan dan Nirmala (2013) yang juga menggunakan kuesioner preferensi gaya belajar persepsi Reid menunjukkan bahwa dari 582 siswa sekolah menengah atas di distrik Salem di negara bagian Tamilnadu, preferensi gaya belajar yang paling perseptual adalah gaya belajar visual dan auditori .

Semua penelitian yang disebutkan di atas menggunakan kuesioner preferensi gaya perseptual yang ditemukan oleh Reid (1987), sejalan dengan instrumen yang digunakan dalam penelitian ini. Sebagian besar hasil menunjukkan bahwa gaya belajar visual adalah yang paling disukai oleh siswa, namun Reid (1987) menyarankan bahwa penelitian tentang gaya belajar masih perlu dilakukan untuk memiliki informasi yang lebih baik, terutama apakah gaya belajar visual masih yang paling gaya belajar yang disukai. Oleh karena itu, penelitian ini bertujuan untuk mengetahui gaya belajar siswa baik utama maupun kedua, apakah gaya belajar visual juga menjadi gaya belajar yang paling disukai oleh siswa, dan untuk melihat apakah ada perbedaan antara preferensi siswa laki-laki dan perempuan berdasarkan tentang Gaya Belajar Perseptual.

\section{METODE PENELITIAN}

Penelitian ini menggunakan desain penelitian kuantitatif. Data yang diambil dari survei yang menggunakan kuesioner yang diberikan kepada siswa dianalisis secara kuantitatif (Kothari, 2004). Data kemudian dioleh untuk mengetahui gaya belajar yang paling disukai oleh siswa, hasil analisa dipresentasikan dalam bentuk tabel untuk kemudian dijabarkan.

Sampel penelitian ini adalah 27 siswa sekolah menengah pertama yang berada di tahun terakhir mereka. Ada 12 siswa perempuan dan 15 siswa laki-laki. Para siswa dipilih berdasarkan salah satu rekomendasi guru bahwa kelas memiliki partisipasi aktif dalam proses pembelajaran di kelas.

Instrumen yang digunakan dalam penelitian ini adalah Angket Gaya Belajar Perceptual Reid. Gaya belajar perseptual Reid terdiri dari tiga puluh pernyataan yang digunakan untuk menentukan enam preferensi gaya belajar belajar: visual, sentuhan, pendengaran, kelompok, kinestetik, individu. Para siswa perlu memberikan skala 5 poin dari setuju, sangat setuju, setuju, ragu-ragu, tidak setuju, sangat tidak setuju terhadap setiap pernyataan yang kemudian akan dianalisis untuk menentukan preferensi gaya belajar siswa yang didasarkan pada klasifikasi Reid: Mayor, Minor dan Negilble.

Variabel penelitian adalah preferensi gaya belajar oleh siswa kelas 9C berdasarkan gaya belajar perseptual yang disarankan oleh Reid (1987).

Peneliti mengambil data untuk penelitian ini menggunakan kuesioner pada tanggal 28 Oktober 2017. Kuesioner diberikan kepada setiap siswa di kelas 9C, peneliti berada di kelas untuk memberikan instruksi yang jelas tentang kuesioner yang diberikan dan membantu siswa untuk memahami masing-masing pernyataan dengan jelas dengan menjelaskannya satu per satu, sehingga siswa dapat memutuskan skala 5 poin dengan jelas.

Selanjutnya, data yang diambil dari kuesioner dianalisis secara kuantitatif berdasarkan instruksi Reid tentang bagaimana menganalisis data untuk preferensi gaya belajar siswa.

Berdasarkan jawaban siswa pada kuesioner yang diberikan, peneliti pertama mengorganisir data dengan mendaftar skor setiap siswa untuk setiap kategori gaya belajar: visual, taktil, pendengaran, kelompok, kinestetik, individu berdasarkan instruksi Reid. Selanjutnya, peneliti menghitung skor total untuk setiap kategori gaya belajar kemudian dibagi skor dengan 27 (jumlah total siswa di kelas) untuk mendapatkan rata-rata setiap kategori gaya belajar. Berdasarkan skor rata-rata setiap kategori, peneliti memutuskan gaya belajar mana yang disukai oleh siswa berdasarkan klasifikasi Reid pada preferensi gaya belajar: Mayor, Minor, Terabaikan.

Data lain yang juga dianalisis adalah skor rata-rata kategori gaya belajar dari siswa laki-laki dan siswa perempuan di kelas untuk melihat apakah gender mempengaruhi 
preferensi gaya belajar siswa. Untuk siswa laki-laki, skor total dibagi dengan 15 (jumlah siswa laki-laki di kelas), sedangkan skor siswa perempuan dibagi dengan 12 (jumlah siswa perempuan di kelas). Kemudian, berdasarkan skor rata-rata setiap kategori dari siswa laki-laki dan juga siswa perempuan, peneliti memutuskan gaya belajar mana yang lebih disukai oleh masing-masing kelompok berdasarkan klasifikasi Reid pada preferensi gaya belajar: Mayor, Minor, Terabaikan.

\section{HASIL DAN PEMBAHASAN}

Berdasarkan hasil penelitian, gaya belajar perseptual yang paling disukai siswa di kelas 9C adalah gaya belajar kelompok dengan nilai rata-rata 38,81 yang diklasifikasikan sebagai gaya belajar utama atau paling diminati berdasarkan klasifikasi Reid. Di tempat kedua adalah gaya belajar auditori dengan rerata 37.85 diklasifikasikan sebagai minor. Gaya belajar pilihan ketiga adalah Kinestetik dengan rerata 37,70 diklasifikasikan sebagai minor. Gaya belajar pilihan keempat adalah Visual dengan rerata 37,33 diklasifikasikan sebagai minor. Gaya belajar pilihan kelima adalah taktil dengan rerata 37,25 diklasifikasikan sebagai minor. Gaya yang paling tidak disukai adalah gaya belajar individu dengan rata-rata 28 diklasifikasikan sebagai minor. Tabel 1 disediakan untuk memiliki data hasil yang sederhana dan jelas.

Tabel 1. Preferensi Gaya Belajar Kelas

\begin{tabular}{lcc}
\hline Gaya Belajar & Nilai rata-rata & Klasifikasi Reid \\
\hline Group & 38.81 & Major \\
\hline Auditory & 37.85 & Minor \\
\hline Kinesthetic & 37.70 & Minor \\
\hline Visual & 37.33 & Minor \\
\hline Tactile & 37.25 & Minor \\
\hline Individual & 28 & Minor \\
\hline
\end{tabular}

Berdasarkan pada tabel 1, dapat disimpulkan bahwa gaya belajar kelompok adalah gaya belajar yang paling disukai di kalangan siswa, karena gaya belajar kelompok memang satu-satunya gaya belajar yang diklasifikasikan sebagai gaya belajar utama berdasarkan hasil. Sedangkan untuk gaya belajar mereka, lima kategori gaya belajar lainnya diklasifikasikan sebagai gaya belajar minor, namun gaya belajar individu memiliki hasil yang sangat berbeda dari yang lain, tampaknya gaya belajar individu adalah gaya belajar yang paling tidak disukai di antara siswa di kelas.

Oflaz dan Turunc (2012) berdasarkan penelitiannya menyatakan bahwa kerja kelompok cenderung memotivasi siswa, sehingga mereka lebih aktif dan antusias dalam proses belajar dan mengajar. Sejalan dengan hasil penelitian, hal tersebut dapat menjadi alasan mengapa gaya belajar kelompok adalah gaya belajar yang paling disukai di kalangan siswa. Sebuah penelitian oleh Farzaneh dan Nejadansari (2014) juga menunjukkan bahwa siswa merasakan keuntungan dari kerja kelompok seperti mereka dapat bergantung pada temanteman mereka sehingga memberi mereka kepercayaan diri untuk menyelesaikan tugas dan menikmati belajar. Misalnya, itu juga dapat menjadi alasan mengapa gaya belajar individu adalah gaya belajar yang paling tidak disukai di antara siswa dibandingkan dengan gaya belajar kelompok.

Mengenai tujuan, apakah siswa pria dan wanita memiliki gaya belajar pilihan yang berbeda, peneliti juga menganalisis data dari skor kelompok siswa pria dan wanita. Hasil penelitian siswa laki-laki menunjukkan bahwa gaya belajar persepsi yang paling disukai adalah gaya belajar kelompok dengan rata-rata 42,13 yang diklasifikasikan sebagai gaya belajar utama. Di tempat kedua adalah gaya belajar visual dengan rata- 
rata 39,06 diklasifikasikan sebagai utama. Gaya belajar yang disukai ketiga adalah Tactile dengan rata-rata 38 diklasifikasikan sebagai utama. Gaya belajar pilihan keempat adalah Kinestetik dengan rata-rata 37,73 diklasifikasikan sebagai minor. Gaya belajar pilihan kelima adalah auditori dengan rerata 37,2 diklasifikasikan sebagai minor. Gaya yang paling tidak disukai adalah pembelajaran individu dengan rerata 27,73 diklasifikasikan sebagai minor.

Tabel 2. Preferensi Gaya Belajar Siswa Laki-laki

\begin{tabular}{lcc}
\hline \multicolumn{1}{c}{ Gaya Belajar } & Nilai rata-rata & Klasifikasi Reid \\
\hline Group & 42.13 & Major \\
\hline Visual & 39.06 & Major \\
\hline Tactile & 38 & Major \\
\hline Kinesthetic & 37.73 & Major \\
\hline Auditory & 37.2 & Major \\
\hline Individual & 27.73 & Minor \\
\hline
\end{tabular}

Di sisi lain, hasil siswa perempuan menunjukkan pada tabel 2 bahwa gaya belajar persepsi yang paling disukai adalah gaya belajar auditori dengan rata-rata 38,66 yang diklasifikasikan sebagai gaya belajar utama. Kedua adalah gaya belajar kinestetik dengan rerata 37,66 diklasifikasikan sebagai minor. Gaya belajar pilihan ketiga adalah Tactile dengan rerata 36,33 diklasifikasikan sebagai minor. Gaya belajar yang disukai keempat adalah visual dengan rata-rata 35,16 diklasifikasikan sebagai minor. Gaya belajar yang disukai kelima adalah kelompok dengan rata-rata 34,66 diklasifikasikan sebagai minor. Gaya yang paling tidak disukai adalah pembelajaran individu dengan rata-rata 28,33 diklasifikasikan sebagai minor.

Tabel 3. Preferensi Gaya Belajar Siswa Perempuan

\begin{tabular}{lcc}
\hline \multicolumn{1}{c}{ Gaya Belajar } & Nilai rata-rata & Klasifikasi Reid \\
\hline Auditory & 38.66 & Major \\
\hline Kinesthetic & 37.66 & Major \\
\hline Tactile & 36.33 & Major \\
\hline Visual & 35.16 & Major \\
\hline Group & 34.66 & Major \\
\hline Individual & 28.33 & Minor \\
\hline
\end{tabular}

Peneliti membuat tabel perbandingan tentang bagaimana gaya belajar yang disukai berbeda dari siswa laki-laki dan perempuan untuk memiliki data yang jelas dan sederhana.

Tabel 4 Perbandingan Preferensi Belajar Siswa Laki vs. Perempuan

\begin{tabular}{lcll}
\hline Siswa Laki-laki & \multicolumn{3}{l}{ Siswa Perempuan } \\
\hline 1. Group & 42.13 & 1. Auditory & 38.66 \\
\hline 2. Visual & 39.06 & 2. Kinesthetic & 37.66 \\
\hline 3. Tactile & 38 & 3. Tactile & 36.33 \\
\hline 4. Kinesthetic & 37.73 & 4. Visual & 35.16 \\
\hline 5. Auditory & 37.2 & 5. Group & 34.66 \\
\hline 6. Individual & 28 & 6. Individual & 28.33 \\
\hline
\end{tabular}


Tabel 5 Perbandingan Preferensi Belajar Siswa Laki vs. Perempuan

\begin{tabular}{lcclc}
\hline & Laki-laki & Perempuan & $\begin{array}{c}\text { Nilai } \\
\text { Tertinggi }\end{array}$ & $\begin{array}{c}\text { Perbedaan } \\
\text { Nilai }\end{array}$ \\
\hline Auditory & 37.2 & 38.66 & Perempuan & 1.46 \\
\hline Kinesthetic & 37.73 & 37.66 & Laki-laki & 0.07 \\
\hline Tactile & 38 & 36.33 & Laki-laki & 1.67 \\
\hline Visual & 39.06 & 35.16 & Laki-laki & 3.9 \\
\hline Group & 42.13 & 34.66 & Laki-laki & 7.47 \\
\hline Individual & 27.73 & 28.33 & Perempuan & 0.33 \\
\hline
\end{tabular}

Berdasarkan Tabel 4 dan 5, perbandingan berdasarkan peringkat antara gaya belajar yang disukai siswa laki-laki dan perempuan, untuk siswa laki-laki, mereka lebih suka gaya belajar kelompok sebagai gaya belajar yang paling disukai mereka, berbeda dengan siswa perempuan yang lebih memilih gaya belajar pendengaran sebagai gaya belajar mereka yang paling disukai. Dapat dilihat pada tabel bahwa hasilnya cukup unik, gaya belajar utama (kelompok) yang disukai oleh siswa laki-laki peringkat sebagai nomor lima untuk siswa perempuan, sedangkan gaya belajar utama yang disukai (pendengaran) dari perempuan peringkat sebagai gaya belajar pilihan kelima untuk siswa pria. Namun, siswa laki-laki dan perempuan paling tidak disukai gaya belajar adalah gaya belajar individu.

Beberapa studi menunjukkan bahwa siswa perempuan memang cenderung lebih menyukai gaya belajar dengan audio daripada siswa laki-laki. Natsir et al., (2016), dalam penelitian mereka menunjukkan bahwa siswa perempuan cenderung lebih suka gaya belajar pendengaran, sedangkan siswa lakilaki cenderung lebih suka gaya belajar visual. Marcus (1999), Sadeghi (2003) dan Natsir et al., (2016) juga menyatakan bahwa siswa perempuan cenderung lebih menyukai gaya belajar pendengaran. Penelitian-penelitian tersebut sejalan dan terkait dengan penelitian yang disarankan oleh Leet-Pellegrim (1980), Aries (1976), Fox (1990), dan Tatarintseva (2002) bahwa siswa perempuan merasa lebih nyaman untuk mendengarkan daripada menunjukkan dibandingkan dengan siswa laki-laki. Dengan demikian, dijelaskan mengapa sebagian besar siswa perempuan dalam beberapa penelitian cenderung lebih suka gaya belajar pendengaran, serta dalam penelitian ini. Juga dijelaskan mengapa siswa laki-laki lebih suka gaya belajar pendengaran sebagai gaya belajar pilihan kelima mereka, karena mereka lebih suka demonstrasi daripada mendengarkan sesuatu, sehingga mereka juga lebih suka gaya belajar visual sebagai gaya belajar pilihan kedua mereka, mereka lebih suka belajar sesuatu melalui melihat, membaca, menonton, misalnya, melihat atau menonton demonstrasi sesuatu.

Meskipun tidak ada perbedaan signifikan antara skor rata-rata siswa laki-laki dan perempuan, dapat disimpulkan bahwa siswa laki-laki dan perempuan memang berbeda secara unik dalam preferensi gaya belajar mereka berdasarkan penelitian ini, di mana siswa perempuan cenderung lebih memilih gaya belajar pendengaran dibandingkan untuk siswa laki-laki yang lebih suka gaya belajar kelompok dan visual, pernyataan ini didukung oleh beberapa studi yang disebutkan di atas oleh Marcus (1999), Sadeghi (2003), Natsir et al., (2006), Leet -Pellegrim (1980), Aries (1976), Fox (1990), dan Tatarintseva (2002) yang menyatakan bahwa siswa perempuan dan laki-laki sebenarnya cenderung memiliki perbedaan dalam preferensi mereka dalam gaya belajar.

\section{KESIMPULAN}

Berdasarkan temuan, dapat disimpulkan bahwa gaya belajar utama siswa adalah gaya belajar kelompok, sedangkan gaya belajar yang paling tidak disukai adalah gaya belajar individu. Untuk siswa lakilaki, gaya belajar utama mereka adalah gaya belajar kelompok yang berbeda dari siswa 
perempuan yang lebih memilih gaya belajar pendengaran sebagai gaya belajar utama mereka. Memang, dapat disimpulkan bahwa pria dan wanita memang unik berbeda dalam preferensi mereka pada gaya belajar.

Hasil ini dapat menjadi informasi bagi guru untuk mempertimbangkan metode dan pendekatan yang digunakan di kelas berdasarkan gaya belajar yang disukai siswa. Namun, disarankan dan direkomendasikan bagi peneliti lain untuk melakukan penyelidikan lebih dalam mengenai preferensi antara siswa laki-laki dan perempuan pada gaya belajar, juga penelitian mengenai gaya belajar apakah gaya belajar pelajar dapat berubah melalui usia dan tingkat pembelajaran, termasuk pengaruhnya. gender.

\section{DAFTAR PUSTAKA}

Aries, E. (1976). Interaction Patterns and Themes of Male, Female, and Mixed Groups. Small Group Behavior, 7(1), 7-18. doi:10.1177/104649647600700102.

Atman, K. S.(1988). Research: Psychological type elements and goal accomplishment style: Implications for distance education. American Journal of Distance Education, 2(3), 36-44. doi:10.1080/08923648809526634.

Babich, A. M., Burdine, P., Albright, L., \& Randol, P. I. (1976). Center for Information Teaching Experiences (CITE) Learning Styles Instrument. Wichita, KA: Murdoch Teachers Center.

Brown, H. Douglas. 2007. Principles of Language Learning and Teaching (5th Edition). White Plain: Pearson Education, Inc.

Claxton, C. S., \& Ralston, Y. (1978). Learning styles: Their impact on teaching and administration. Washington, DC: American Association for Higher Education.

Dunn, R.S. and Dunn, K. (1992). Teaching Elementary Students Through Their Individual Learning Styles: Practical Approaches for Grades 3-6. Needham Heights, MA: Allyn and Bacon.

Ehrman, M., \& Leaver, B. L. (2003). Cognitive styles in the service of language learning. System, 31(3), 393-415, doi: 10.1016/s0346-251x(03)00050-2.

Farzaneh, N. \& Nejadansari, D. (2014). Students' Attitude towards Using Cooperative Learning for Teaching Reading Comprehension. Academy Publisher Manufactured in Finland. Theory and Practice in Language Studies, Vol 4(2), pp. 287-292. https://pdfs.semanticscholar.org/883c/ae9e16828f48b6f57884d1de9e220e4a6ac1.pdf.

Fox, T. (1990). Gender Interest in Reading and Writing. Norwood, NJ: Ablex.

Gilakjani, A. P. (2012). Visual, Auditory, Kinaesthetic Learning Styles and Their Impacts on English Language Teaching. Journal of Studies in Education, 2(1), 104-113. doi:10.5296/jse.v2i1.1007.

Griffith, C. (Ed.). (2008). Lessons from Good Language Learners. Cambridge: Cambridge University Press. 324pp. ISBN 978-0-521-71814-1.

Hudson, L. (1966). Contrary imaginations. Harmondsworth: Penguin.

Kagan, J. (1965). Impulsive and reflective children: significance of conceptual tempo. In J.D. Krumboltz (ed.), Learning and the Educational Process. Chicago, IL: Rand McNally, pp. 133-161.

Karthigeyan, K., \& Nirmala, K. (2013). Learning Style Preference of English Language Learners. Educationia Confab, 2(1), 134-140. https://pdfs.semanticscholar.org/606c/5610f3ff8c8e6ef7fcafc6a9bdbc25f6849a. pdf.

Kirby, J. (1988). Style, Strategy, and Skills in Reading. In R.R. Schmeck (ed.), Learning Strategies and Learning Styles. New York: Plenum, 229-274.

Kogan, N. (1971). Educational implications of cognitive styles. In G.S. Lesser (ed.), Psychology and Educational Practice. Glenview, IL: Scott, Foresman \& Company, pp. 242-292.

Kogan, N., \& Wallach, M. A. (1964). Risk-taking: A Study in Cognition and Personality. New York: Holt, Rinehart, and Winston.

Kothari, C. R. (2004). Research Methodology: Methods and Techniques (Second Revision Edition). New Age International Publishers.

Leet-Pellegrini, H. (1980). Conversational Dominance as a Function of Gender and Expertise. In Language: Social Psychological Perspectives, eds. H. Giles, W. Robinson \& P.Smith. New York: Pergamon. 
Lewenfeld, V. (1945). Tests for visual and haptical aptitudes. American Journal of Psychology, 58, 100-112.

Marcus, L. (1999). A Comparison of Selected Male and Female Students' Learning Styles. New York: Oxford University Press.

Natsir, Y., Yusuf, Y. Q., \& Huri, A. D. (2016). The Male and Female EFL Students' Language Learning Styles. Proceedings of English Education International Conference, 1, 66-73.

Nel, C. (2008). Learning Style and Good Language Learners. In C. Griffith (ed), Lessons from Good Language Learners. (Cambridge Language Teaching Library). Cambridge: Cambridge University Press.

Obralic, N., \& Akbarov, A. (2012). Students Preferences on Perceptual Learning Style. Acta Didactica Napocensia, $5(5), 31-42$.

Oflaz, M., \& Turunc, T. (2012). The Effect of Learning Styles on Group Work Activities. Procedia - Social and Behavioural Sciences, 46, 1333 - 1338.

Oxford, R. L. (1993). Style Analysis Survey (SAS). Tuscaloosa, AL: University of Alabama.

Pask, G. (1972). A fresh look at cognition and the individual. International Journal of Man-Machine Studies, 4, 211-216.

Peters A. M. (1977). Language learning strategies: does the whole equal the sum of the parts? Language, 53, $560-573$.

Reid, J. (1987). The Learning Style Preferences of ESL Students. TESOL Quarterly, 21(1), 87-111.

Richardson, A. (1977). Verbalizer-visualizer: a cognitive style dimension. Journal of Mental Imagery, 1(1), 109126.

Sadeghi, M. R. (2013). EFL male and female learning styles and multiple intelligences: A case of Iranian EFL university students. Iranian Journal of Research in English Language Teaching, 1(2), 33-46.

Schmeck, R. R. (1981). Improving learning by improving thinking. Educational Leadership, 38, 384.

Skehan, P. (1991). Individual Differences in Second Language Learning. Studies in Second Language Acquisition, 13, 275-298.

Tatarintseva, A. (2002). The Influence of the Gender Factor to the Learning Styles of Secondary Students in the Process of Language Learning. Kalbu Studijos. Studies About Languages, No. 2, pp. 63-68.

Torrance, E. P., \& Rockenstein, Z. L. (1988). Styles of thinking and creativity. In R.R. Schmeck (ed.), Learning strategies and learning styles. New York: Plenum Press, 275-290.

Witkin, H., Lewis, H., Hertzman, M., Machover, K., Meissner, P., \& Wapner, S. (1954). Personality Through Perception. New York: Harper. 